KHAZANAH MULTIDISIPLIN

VOL 2 NO 22021

https://journal.uinsgd.ac.id/index.php/kl

\title{
RETURN SAHAM PADA PERUSAHAAN YANG LISTING DI JAKARTA ISLAMIC INDEX (JII): DITINJAU DARI TINGKAT INFLASI DAN BESARNYA DEBT TO EQUITY RATIO (DER)
}

\author{
Nia Kurnia Lestari', Muhammad Bilal Abdul Aziz ${ }^{2}$ \\ 1,2 UIN Sunan Gunung Djati Bandung, Bandung, Indonesia \\ E-mail: niakurnialestario2@gmail.com
}

Diterima : 1 January 2021, Revisi : 10 May 2021 Disetujui : 25 Juny 2021

\begin{abstract}
ABSTRAK
Penelitian ini bertujuan untuk mengetahui berapa besar pengaruh tingkat Inflasi dan Debt to Equity Ratio (DER) terhadap Return Saham PT. Unilever indonesia, Tbk. Metode yang digunakan adalah metode deskriptif dan analisis kuantitatif yaitu menggunakan analisis regresi, uji korelasi, analisis determinasi dan analisis uji t dan uji f, dengan menggunakan aplikasi sebagai alat bantu perhitungan. Laporan keuangan PT. Unilever Indonesia, Tbk. periode 2005-2015 dijadikan sebagai data yang digunakan. Penelitian ini menunjukkan hasil uji signifikansi yang cukup kuat antara Debt to Equity Ratio (DER) terhadap Return Saham (Y) yang berarti bahwa Rasio Solvabilitas yaitu Debt to Equity Ratio (DER) terkhusus dalam penelitian ini memiliki hubungan yang cukup erat terhadap pembagian Return Saham pada perusahaan yang listing di Jakarta Islamic index (JII) terutama di PT Unilever Indonesia.

Kata kunci: Debt to Equity Ratio (DER), Inflasi, Jakarta Islamic Index, Return Saham.
\end{abstract}

\section{ABSTRACT}

This study aims to determine how much influence the level of Inflation and Debt to Equity Ratio (DER) on the Stock Return of PT. Unilever Indonesia, Tbk. The method used is descriptive method and quantitative analysis using regression analysis, correlation test, analysis of determination and analysis of t test and $\mathrm{f}$ test, using the application as a calculation tool. PT. Unilever Indonesia, Tbk. the period 2005-2015 is used as the data used. This study shows the results of a fairly strong significance test between the Debt to Equity Ratio (DER) to Stock Return (Y) which means that the Solvency Ratio, namely the Debt to Equity Ratio (DER), especially in this study has a fairly close relationship to the distribution of Stock Return in companies that are listed on the Jakarta Islamic index (JII), especially at PT Unilever Indonesia.

Keywords: Debt to Equity Ratio (DER), Inflation, Jakarta Islamic Index, Stock Return.

\section{PENDAHULUAN}

Pasar modal adalah segala kegiatan yang berkaitan dengan penawaran umum perdagangan efek perusahaan publik yang berkaitan dengan produk dan dapat dikelola tanpa memandang status gender (Noorchasanah, 2020; Wiryadinata, 2020). Dalam arti sempit, pasar modal adalah suatu pasar yang dana-dana jangka panjang, baik dana dalam bentuk utang maupun dana dalam bentuk modal di perdagangkan (Fathoni, 
2021). Dengan kata lain, pasar modal merupakan tempat pertemuan antara penawaran dan permintaan surat berharga. Jenis surat berharga yang diperjualbelikan di pasar modal diantaranya: surat berharga yang merupakan modal, berbentuk saham biasa (common stock) dan saham preferen (preferen stock), sedangkan surat berharga yang merupakan utang berbentuk obligasi (bond) (Khairunnisa, 2020). Undang-Undang Pasar Modal No. 8 tahun 1995 tentang Pasar Modal mendefinisikan pasar modal sebagai kegiatan yang bersangkutan dengan Penawaran Umum dan perdagangan Efek, Perusahaan Publik yang berkaitan dengan Efek yang diterbitkannya, serta lembaga dan profesi yang berkaitan dengan Efek. (Fadilah Haidar, 2015)

Bursa efek Indonesia memiliki berbagai jenis indeks yang diperdagangkan, salah satunya adalah Jakarta Islamic Index (JII) yang dikembangkan oleh Bursa Efek Indonesia (BEI) bersama dengan PT. Danareksa Invesment Management. Indeks yang pertama kali diluncurkan pada 3 Juni 2000 ini terdiri dari 30 saham yang dipilih dari saham-saham yang sesuai dengan syariah islam (Prasetyo, 2018). Pemilihannya dilakukan atas kerjasama dengan Dewan Syariah Nasional. Hal ini tertuang dalam Peraturan Bapepam-LK Nomor II.K.1 tentang Kriteria dan Penerbitan Daftar Efek Syariah. Meskipun saat ini seluruh kewenangan Bapepam-LK dilimpahkan pada Otoritas Jasa keuangan (OJK) sejak tahun 2011. Sahamsaham yang terdaftar di Jakarta Islamic Index (JII) selalu dilakukan evaluasi periodik enam bulanan yang diseleksi dari daftar saham atau efek syariah sebagaimana yang telah ditetapkan oleh Otoritas Jasa Keuangan (Senjani and Wibantoro, 2018). Pesatnya perkembangan Bursa Efek Indonesia (BEI) saat ini tidak dapat dipisahkan dari peran investor yang melakukan transaksi di Bursa Efek Indonesia (BEI). Sebelum seorang investor memutuskan akan menginvestasikan dananya di pasar modal, ada kegiatan penting yang perlu dilakukan dan dipahami oleh investor (Syahbudi and Barus, 2019).

Berinvestasi di pasar modal diharapkan dapat meningkatkan laba 
perusahaan. Investasi sendiri merupakan suatu kegiatan menempatkan dana pada satu atau lebih aset selama periode tertentu dengan harapan dapat memperoleh pendapatan atau peningkatan atas nilai investasi awal (modal) yang bertujuan untuk memaksimalkan hasil (return) yang diharapkan dalam batas risiko yang dapat diterima untuk tiap investor. (Laely Purnamasari, 2017). Return adalah salah satu faktor yang memotivasi investor untuk berinvestasi dan juga merupakan imbalan atas keberanian investor menanggung risiko atas investasi yang dilakukannya.(Tandelilin, 2001, p. 47)

PT. Unilever Indonesia, Tbk. merupakan salah satu perusahaan yang terdaftar dan konsisten berada dalam perhitungan saham Jakarta Islamic Index (JII). PT. Unilever Indonesia, Tbk. melepas 15\% sahamnya di Bursa Efek Jakarta dan Bursa Efek Surabaya pada tahun 1981. Perusahaan tersebut merupakan perusahaan yang tercatat harga sahamnya terus mengalami kenaikan. Kenaikan harga saham belum tentu sebanding dengan pembagian return saham perusahaan tersebut. Berikut data return saham PT. Unilever Indonesia, Tbk. serta indikator eksternal dan indikator internal perusahaan yang berpengaruh terhadap return saham.

Tabel 1. Tingkat Inflasi, Debt to Equity Ratio (DER), dan Return Saham PT. Unilever Indonesia Tbk Periode 2005-2016 dalam \%

\begin{tabular}{|c|c|c|c|}
\hline Periode & Inflasi & DER & Return \\
\hline 2005 & 17,11 & 0,76 & 29,55 \\
\hline 2006 & 6,6 & 0,95 & 54,39 \\
\hline 2007 & 6,59 & 0,98 & 2,27 \\
\hline 2008 & 11,06 & 1,10 & 15,56 \\
\hline 2009 & 2,78 & 0,92 & 41,67 \\
\hline 2010 & 6,96 & 1,15 & 49,32 \\
\hline 2011 & 3,79 & 1,85 & 13,94 \\
\hline 2012 & 4,3 & 2,02 & 10,90 \\
\hline 2013 & 8,38 & 2,14 & 24,70 \\
\hline 2014 & 8,36 & 2,11 & 24,23 \\
\hline 2015 & 3,35 & 2,26 & 14,55 \\
\hline 2016 & 3,02 & 2,56 & 4,86 \\
\hline
\end{tabular}

Sumber: Laporan Keuangan Tahunan PT Unilever Indonesia Tbk ( 
KHAZANAH MULTIDISIPLIN

VOL 2 NO 22021

https://journal.uinsgd.ac.id/index.php/kl

www.bps.go.id )

Berdasarkan tabel 1 dua indikator utama yaitu tingkat inflasi dan Debt To Equity Ratio (DER) terlihat tidak stabil karena mengalami kenaikan dan penurunan dari tahun ke tahun. Hal ini juga nampak pada tingkat return saham yang sama-sama mengalami tren berfluktuasi dari tahun ke tahun (Arisa, 2017; Afrilia, 2020). Pada tahun 2006 inflasi mengalami penurunan dari $17,11 \%$ menjadi 6,60\%, sedangkan Debt To Equity Ratio (DER) dan return saham mengalami kenaikan dari masingmasing 0,76\% dan 29,55\% menjadi 0,95\% dan 54,39\%. Sedangkan pada tahun 2007 inflasi mengalami penurunan o,01\% menjadi 6,59\%, Debt To Equity Ratio (DER) kembali mengalami kenaikan menjadi 0,98\% dan return saham pada tahun 2007 mengalami penurunan yang cukup signifikan yaitu mencapai 52\% menjadi 2,27\%. Pada tahun 2008 dan 2010 ketiganya mengalami kenaikan masing masing 11,06\%, 1,10\%, 15,56\% dan $6,96 \%, 1,15 \%, 49,32 \%$ yang mana pada tahun 2009 besarnya inflasi adalah 2,78\%, Debt To Equity Ratio (DER) 0,92\% dan return saham 41,67\%.

Tahun 2011 inflasi dan return saham mengalami penurunan menjadi 3,79\% dan 13,94\% sedangkan Debt To Equity Ratio (DER) mengalamin kenaikan menjadi 1,85\%. Tahun 2012 inflasi mengalami kenaikan menjadi 4,30\% sejalan dengan Debt To Equity Ratio (DER) yang berubah menjadi 2,02\% mengakibatkan penurunan return saham menjadi 10,90\%. Pada tahun 2013 dan 2014 ketiganya mengalami kenaikan dan penurunan secara bersama-sama yaitu tahun 2013 inflasi sebesar 8,38\%, Debt To Equity Ratio (DER) 2,14\% dan return saham 24,70\%, tahun 2014 inflasi sebesar 8,36\%, Debt To Equity Ratio (DER) 2,11\% dan return saham 24,23\%. Pada tahun 2015 dan 2016 inflasi pengalami penurunan menjadi 3,35\% dan 3.02\%, Debt To Equity Ratio (DER) mengalami kenaikan menjadi 2,26\% dan 2,56\% sedangkan return saham mengalami penurunan menjadi 14,55\% dan 4,36\%. Berikut merupakan grafik yang dapat menggambarkan fluktuasi inflasi, Debt To Equity Ratio (DER), dan return saham.

Tabel 1 menggambarkan indikator mana yang sangat berpengaruh 
pada tingkat return saham. Faktor utama yang nampak sangat berpengaruh pada tingkat return saham ialah tingkat inflasi. Secara umum inflasi berarti kenaikan tingkat harga secara umum dari barang/komoditas dan jasa selama suatu periode waktu tertentu. (Karim, 2012, p. 135). Tingkat inflasi biasanya dikaitkan dengan kondisi ekonomi yang ekstrim, dalam kondisi yang ekstrim tersebut harga barang secara umum mengalami kenaikan secara terus menerus atau terjadi penurunan nilai mata uang dalam negeri. Tingginya tingkat inflasi menunjukan bahwa risiko untuk melakukan investasi cukup besar sebab inflasi yang tinggi akan mengurangi tingkat pengembalian (rate of return) dari investor. Pada kondisi inflasi yang tinggi maka harga barang-barang atau bahan baku memiliki kecenderungan untuk meningkat. (Suyati, 2015). Peningkatan harga barang-barang dan bahan baku akan membuat biaya produksi menjadi tinggi sehingga akan berpengaruh pada penurunan jumlah permintaan yang berakibat pada penurunan penjualan sehingga akan mengurangi pendapatan perusahaan. Selanjutnya akan berdampak buruk pada kinerja perusahaan yang tercrmin pula oleh turunnya return saham. (Prihantini, 2009).

Debt to Equity Ratio (DER) akan mempengaruhi kinerja perusahaan dan menyebabkan apresiasi dan depresiasi harga saham. (Sulaeman et al., 2018). Semakin besar Debt to Equity Ratio (DER) menandakan struktur permodalan usaha lebih banyak memanfaatkan utang-utang relatif terhadap ekuitas. Semakin besar Debt to Equity Ratio (DER) mencerminkan risiko perusahaan yang relatif tinggi akibat para investor cenderung menghindari saham-saham yang memiliki nilai Debt to Equity Ratio (DER) yang tinggi. Beberapa perusahaan yang memiliki Debt To Equity Ratio (DER) lebih dari satu akan mengganggu pertumbuhan kinerja perusahaan juga mengganggu pertumbuhan harga saham, karena itu sebagian besar para investor menghindari perusahaan yang memiliki angka Debt To Equity Ratio (DER) lebih dari dua. Penggunaan utang oleh suatu perusahaan akan membuat risiko yang ditanggung pemegang saham meningkat. Ketika terdapat penambahan jumlah hutang secara absolut 
pada suatu perusahaan maka hal tersebut akan menurunkan tingkat solvabilitas perusahaan, yang selanjutnya berdampak dengan menurunnya nilai (return) saham. (Prihantini, 2009). Faktor eksternal tingkat inflasi dan faktor internal Debt To Equity Ratio (DER) merupakan beberapa faktor yang diprediksi bisa berpengaruh terhadap penerimaan return saham yang diharapkan para investor yang sudah menanamkan modal di PT. Unilever Indonesia, Namun hal ini masih membutuhkan beberapa penelitian untuk mendapatkan analisis yang maksimal, untuk mengisi kekurangan ini kami bermaksud untuk mengetahui berapa besar pengaruh tingkat Inflasi dan Debt to Equity Ratio (DER) terhadap Return Saham PT. Unilever indonesia Tbk sehingga dapat dijadikan pijakan analisis diperusahaan-perusahaan lainnya yang terdaftar di bursa efek Indonesia.

\section{METODE PENELITIAN}

Metode analisis data yang digunakan dalam penelitian ini bersifat deskriptif kuantitatif (Martono, 2019). Analisis dilakukan melalui pendekatan kuantitatif dengan metode statistik untuk menguji hipotesis, yaitu untuk membuktikan apakah data yang dianalisa tersebut berpengaruh atau tidak yaitu apakah ada pengaruh antara tingkat inflasi dan Debt to Equity Ratio (DER) terhadap return saham.

Analisis statistik deskriptif merupakan statistik yang berfungsi untuk mendeskripsikan atau memberi gambaran terhadap obyek yang diteliti melalui data sampel atau populasi sebagaimana adanya, tanpa melakukan analisis dan membuat kesimpulan yang berlaku untuk umum. (Sugiono, 2013, p. 29). Dalam jenis penelitian kuantitatif, analisis deskriptif disusun ke dalam bentuk tabel, kurva, atau diagram sebagai bahan dasar untuk dijelaskan secara naratif dan deskriptif.

Analsis kuantitatif adalah analsiis yang menggunakan rumus-rumus statistik dalam pengujiannya. Alat analisis yang digunakan untuk menguji hipotesis yaitu dengan menggunakan analisis deskriptif, analisis regresi linier sederhana dan berganda, analisis korelasi pearson product moment, 
koefisien determinasi, uji signifikansi Uji t (Parsial), dan Uji f (Simultan).

Penelitian ini menggunakan data sekunder yang berupa data tahunan periode 2005 sampai 2016. Data bersumber dari laporan keuangan PT. Unilever Indonesia, Tbk. yang dipublikasi oleh Bursa Efek Indonesia, dan Badan Pusat Statistik (BPS) berupa rasio keuangan dan presentasi tingkat inflasi serta berbagai literatur seperti buku, jurnal, penelitian terdahulu dan media elektronik.

\section{HASIL DAN PEMBAHASAN}

Metode analisis yang digunakan dalam penelitian ini adalah dengan melakukan analisis kuantitatif yang dinyatakan dengan angka-angka yang perhitungannya menggunakan metode statistik yang dibantu dengan program pengolahan data statistik. Berdasarkan data yang telah disajikan pada tabel 1, terdapat hasil dari perhitungan tersebut sebagai berikut:

\section{Analisis Deskriptif}

Tingkat Inflasi sebagai Variabel $X_{1}$, Debt to Equity Ratio (DER) sebagai variabel $X_{2}$ dan Return Saham sebagai variabel $Y$. Berikut merupakan data statistik deskriptif dari variabel-variabel terkait:

Tabel 2. Hubungan Inflasi $\left(X_{1}\right)$, Debt to Equity Ratio (DER) $\left(X_{2}\right)$ dan Return Saham pada PT Unilever Indonesia, Tbk periode 2005-2016

Descriptive Statistics

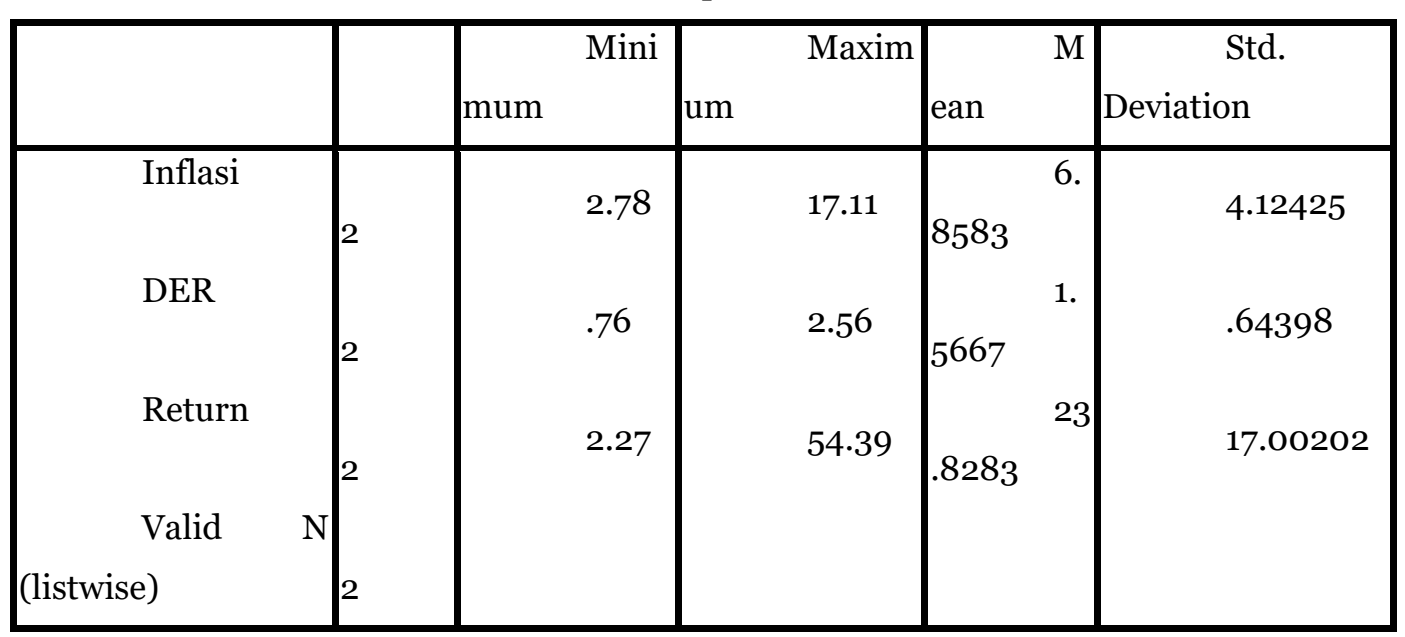

Sumber: Output SPSS for Windows 16.o (Data diolah peneliti)

Dari tabel 2 menunjukkan bahwa $\mathrm{N}$ adalah jumlah data yang diteliti, 
dalam penelitian ini jumlah data yang diteliti adalah 12 data dari dua variabel Inflasi $\left(\mathrm{X}_{1}\right)$, Debt to Equity Ratio (DER) $\left(\mathrm{X}_{2}\right)$ dan Return Saham (Y). Untuk Indeks Inflasi $\left(\mathrm{X}_{1}\right)$ memperoleh nilai Minimum sebesar 2,78 sedangkan nilai Maksimum memperoleh nilai 17,11, kemudian untuk nilai rata-rata atau Mean dari Inflasi $\left(\mathrm{X}_{1}\right)$ memperoleh nilai 6,8583 dengan Standar Deviasi memperoleh nilai 4,12425.

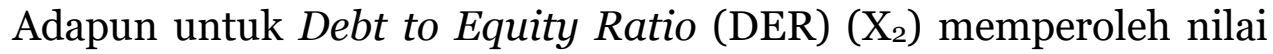
Minimum sebesar 0,76, sedangkan nilai Maksimum-nya 2,56 dengan nilai rata-rata atau Mean sebesar 1,5667, dimana Standar Deviasi untuk Debt to Equity Ratio (DER) $\left(\mathrm{X}_{2}\right)$ ini sebesar o,64398.

Untuk Return Saham (Y) memperoleh nilai Minimum sebesar 2,27, sedangkan nilai Maksimumnya sebesar 54,39 dengan nilai rata-rata atau Mean sebesar 23.8283 dimana Standar Deviasi dari Return Saham (Y) ini adalah 17.00202.

\section{Uji Asumsi Klasik}

Uji asumsi klasik yang digunakan peneliti antara lain, uji normalitas, multikolinearitas, heterokedastisitas, dan autokorelasi.

\section{Uji Normalitas}

Uji normalitas bertujuan untuk menguji apakah dalam model regresi, variabel terikat dan variabel bebas keduanya mempunyai distribusi normal atau tidak. Uji normalitas bisa menggunakan uji P-P Plot, Histogram dan Kolmogrov-Sminov. Berikut hipotesis dari uji normalitas:

$\mathrm{H}_{\mathrm{o}}=$ Model berdistribusi normal;

$\mathrm{H}_{1}=$ Model tidak berdistribusi normal.

Untuk menguji normalitas data, teknik yang digunakan peneliti adalah uji Kolmogrov-Smirnov untuk memperjelas dengan angka. Jika signifikansi pada nilai Kolmogrov-Smirnov < 0,05 maka $\mathrm{H}_{\mathrm{o}}$ ditolak, jadi data residual berdistribusi tidak normal. Jika signifikansi pada nilai Kolmogrov-Smirnov > 0,05 maka $\mathrm{H}_{0}$ diterima, jadi data residual berdistribusi normal. Perhitungan menggunakan aplikasi SPSS versi 16.o menunjukan hasil sebagai berikut: 
KHAZANAH MULTIDISIPLIN

VOL 2 NO 22021

https://journal.uinsgd.ac.id/index.php/kl

Tabel 3. Uji Normalitas menggunakan Kolmogrov-Smirnov

One-Sample Kolmogorov-Smirnov Test

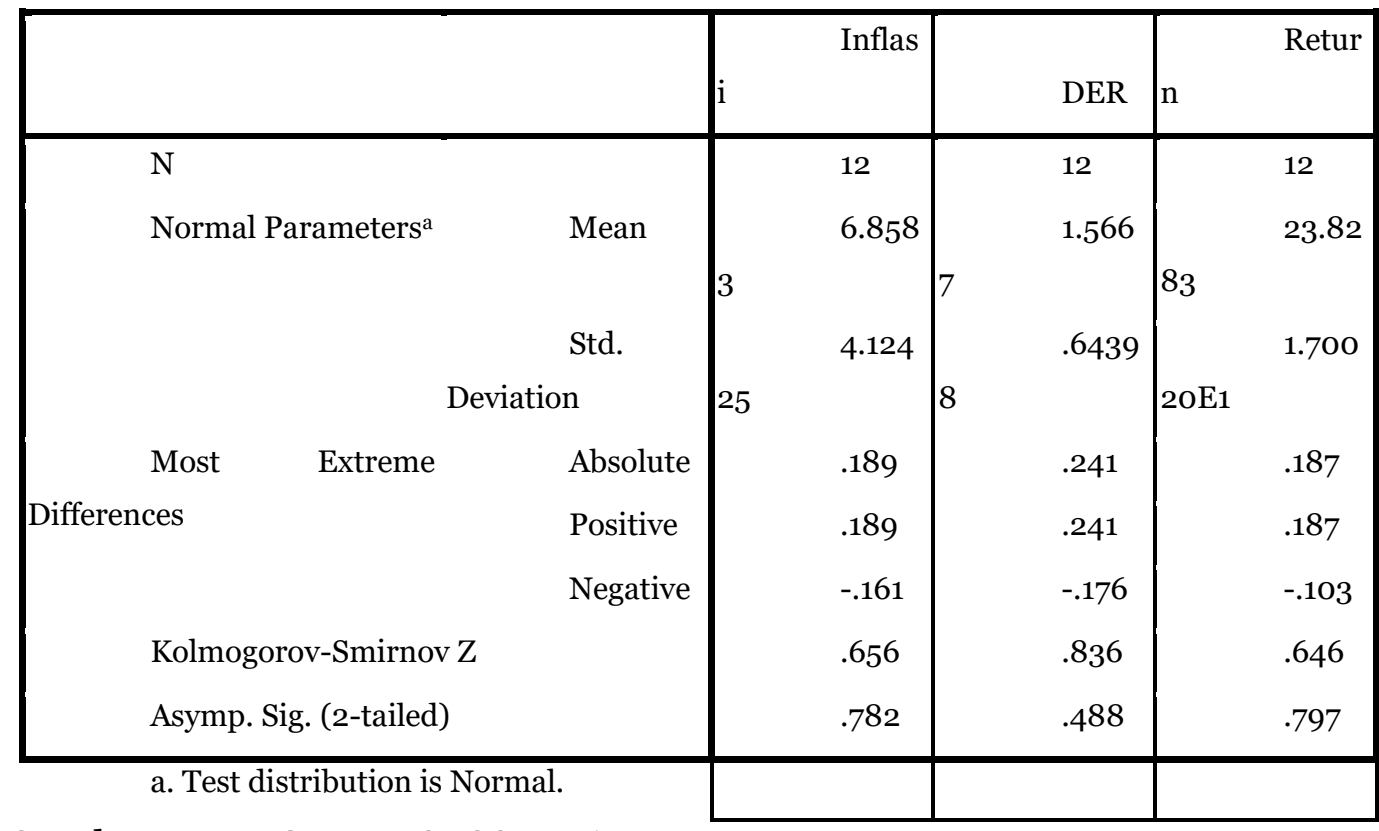

Sumber Data: Output SPSS V.16.0

Pada tabel 3 diatas nilai signifikansi tiap variabel lebih > dari 0,05 yaitu 0,782 untuk Inflasi; 0,488 untuk Debt to Equity ratio (DER); dan 0,797 untuk Return Saham, maka $\mathrm{H}_{\mathrm{o}}$ diterima artinya data berdistribusi normal sehingga uji normalitas bisa terpenuhi.

Selain menggunakan uji Kolmogrov-Smirnov, ada cara lain untuk menentukan data berdistribusi normal atau tidak dengan menggunakan rasio skewness dan rasio kurtosis, yaitu bila rasio kurtosis dan skewness berada di antara -2 dan +2 , maka data adalah normal. Berikut merupakan menghitungannya:

Tabel 4 Uji Normalitas menggunakan Rasio Skewness dan Kurtosis Descriptive Statistics

\begin{tabular}{|l|l|l|l|l|l|}
\hline \multirow{2}{*}{} & N & \multicolumn{3}{|l|}{ Skewness } & \multicolumn{2}{l|}{ Kurtosis } \\
\cline { 2 - 6 } & Statistic & Statistic & Std. Error & Statistic & Std. Error \\
\hline Unstandardized Residual & 12 & -.474 & .637 & .538 & 1.232 \\
Valid N (listwise) & 12 & & & & \\
\hline
\end{tabular}

Terlihat pada tabel 4 bahwa rasio skewness $=-0,474 / 0,637=-$ 
0,744; sedangkan rasio kutosis $=0,538 / 1,232=0,437$. Karena rasio skewness dan rasio kutosis berada di antara -2 hingga +2, maka dapat disimpulkan bahwa distribusi data adalah normal.

\section{Uji Autokorelasi}

Autokorelasi digunakan untuk menguji apakah dalam model regresi linier ada korelasi antara kesalahan pengganggu (residual) pada periode tertentu ( $\mathrm{t}$ ) dengan kesalahan pengganggu (residual) pada periode sebelumnya (t-1) tidak adanya serial korelasi, teknik yang digunakan peneliti adalah Durbin-Waston (DW Test). Hipotesis yang akan di uji adalah:

$\mathrm{H}_{\mathrm{o}}=$ Tidak ada Autokorelasi

$\mathrm{H}_{\mathrm{a}}=$ Ada Autokorelasi.

Tabel 5. Uji Autokorelasi

Runs Test

\begin{tabular}{|c|c|c|}
\hline & & $\begin{array}{l}\text { Unstanda } \\
\text { rdized Residual }\end{array}$ \\
\hline tailed) & $\begin{array}{l}\text { Test Value }^{\mathrm{a}} \\
\text { Cases }<\text { Test Value } \\
\text { Cases > } \quad \text { Test } \\
\text { Total Cases } \\
\text { Number of Runs } \\
\text { Z } \\
\text { Asymp. Sig. }\end{array}$ & $\begin{array}{l}-1.05705 \\
6 \\
6 \\
12 \\
7 \\
.000 \\
\text { 1.00o }\end{array}$ \\
\hline
\end{tabular}

Dari hasil output di atas didapat nilai Asympg. Sig. (2-tailed) > 0.05 yaitu sebesar 1.000 yang berarti hipotesis nol diterima residual random (acak). Dengan demikian, data yang dipergunakan cukup random tidak terdapat masalah autokorelasi pada data yang di uji.

\section{Uji Multikolinearitas}

Uji multikolinearitas bertujuan untuk menguji apakah dalam model regresi ditemukan adanya korelasi antara variabel bebas atau tidak. Model yang baik seharusnya tidak terjadi korelasi yang tinggi diantara variabel 
bebas. Untuk mendeteksi ada atau tidaknya multikolinearitas di dalam model regresi, dapat diketahui dari nilai tolerance dan Variance Inflation Factor (VIF), yakni:

1. Jika nilai tolerance lebih besar dari o,10 maka artinya tidak terjadi multikolinearitas terhadap data yang diuji;

2. Jika nilai tolerance lebih kecil dari o,10 maka artinya terjadi multikolinearitas terhadap data yang diuji;

3. Jika nilai VIF lebih besar dari 10,00 maka artinya tidak terjadi multikolinearitas terhadap data yang diuji;

4. Jika nilai VIF lebih kecil dari 10,00 maka artinya terjadi multikolinearitas terhadap data yang diuji.

Perhitungan menggunakan aplikasi SPSS versi 16 menunjukan hasil sebagai berikut:

Tabel 6. Uji Multikolinearitas VIF Coefficients $^{\mathrm{a}}$

\begin{tabular}{|cc|c|c|}
\hline \multirow{2}{*}{} & & \multicolumn{2}{|c|}{ Collinearity Statistics } \\
\cline { 3 - 4 } Model & Toleranc & VIF \\
\hline 1 & (Constant & & \\
& & & \\
& Inflasi & .773 & 1.293 \\
& DER & .773 & 1.293 \\
\hline
\end{tabular}

a. Dependent Variable: Return

\section{Sumber Data: Output SPSS V.16}

Pada tabel di atas nilai tolerance 0,773 > 0,10 dan nilai VIF 1,293< 10,00 sehingga dapat disimpulkan tidak terdapat multikolinearitas atau $\mathrm{H}_{\mathrm{o}}$ di terima tidak terjadi multikolinearitas artinya uji multikolinearitas terpenuhi. Selain itu, uji multikolinieritas dapat juga dilakukan dengan melihat keeratan hubungan anatara dua variabel penjelas atau yang lebih dikenal dengan istilah korelasi, yaitu dengan melihat nilai significance (2-tailed), jika nilainya lebih kecil dari o,05 maka diindikasikan memiliki gejala multikolinearitas yang serius. Sebaliknya jika nilai significance (2-tailed) 
KHAZANAH MULTIDISIPLIN

VOL 2 NO 22021

https://journal.uinsgd.ac.id/index.php/kl

lebih besar dari o,05 maka diindikasikan data tersebut terbebas dari gejala multikolinearitas.

Tabel 7. Uji Multikolinearitas Menggunakan Korelasi Correlations

\begin{tabular}{|lll|l|l|}
\hline Control Variables & & Inflasi & DER \\
\hline Return $\quad$ Inflasi & Correlation & 1.000 & -.466 \\
& Significance (2-tailed) &. & .148 \\
& Df & 0 & 9 \\
\hline DER & Correlation & -.466 & 1.000 \\
& Significance (2-tailed) & .148 &. \\
& Df & 9 & 0 \\
\hline
\end{tabular}

Dilihat dari hasil perhitungan di atas bahwa nilai significance (2tailed) lebih besar dari 0,05 yaitu 0,148>0,05 sehingga dapat disimpulkan bahwa seluruh variabel penjelas terbebas dari masalah multikolinearitas.

\section{Uji Heteroskedastisitas}

Uji heterokedastisitas bertujuan untuk menguji apakah dalam model regresi terjadi ketidaksamaan variance dari residual pengamatan satu ke pengamatan yang lain. Kriteria dalam menentukan uji heterokedastisitas adalah sebagai berikut:

Ada pola tertentu, seperti titik-titik yang ada membentuk pola tertentu yang teratur (bergelombang, melebar kemudian menyempit), maka mengindikasikan telah terjadi heterokedastisitas;

1. Jika tidak ada pola tertentu dan tidak menyebar diatas dan dibawah angka nol pada sumbu Y, maka tidak terjadi heterokedastisitas;

2. Jika nilai signifikansi lebih besar dari 0,05, kesimpulannya adalah tidak terjadi heterokedastisitas;

3. Jika nilai signifikansi lebih kecil dari 0,05, kesimpulannya adalah terjadi heterokedastisitas. 
KHAZANAH MULTIDISIPLIN

VOL 2 NO 22021

https://journal.uinsgd.ac.id/index.php/kl

Tabel 8. Uji Heteroskedastisitas

Coefficients $^{\mathrm{a}}$

\begin{tabular}{|c|l|l|l|l|l|}
\hline \multirow{2}{*}{} & \multicolumn{2}{|l|}{$\begin{array}{l}\text { Unstandardized } \\
\text { Coefficients }\end{array}$} & $\begin{array}{l}\text { Standardized } \\
\text { Coefficients }\end{array}$ & \\
\cline { 2 - 6 } Model & $\mathrm{B}$ & Std. Error & Beta & S & Sig. \\
\hline (Constant) & 27.508 & 10.318 & & 2.666 & .026 \\
Inflasi & -.583 & .687 & -.275 & -.849 & .418 \\
DER & -7.972 & 4.403 & -.588 & -1.811 & .104 \\
\hline
\end{tabular}

a. Dependent Variable: abresid

Hasil statistik menunjukan bahwa nilai t-statistik dari seluruh variabel penjelas tidak ada yang signifikan secara statistik, dan nilai signifikansi > 0,005 yaitu 0,418 dan 0,104. Dengan demikian, dapat dikatakan bahwa penelitian ini bebas dari masalah heteroskedastisitas.

Pengaruh Inflasi ( $\left.X_{1}\right)$ dan Debt to Equity Ratio (DER) (X) terhadap Return Saham (Y) PT Unilever Indonesia, Tbk.

Teknis analisis data yang digunakan adalah dengan analisis regresi linier berganda, uji korelasi, analisis determinasi, dan uji hipotesis sebagai berikut:

\section{Analisis Regresi Linier Berganda}

Berikut merupakan hasil perhitungan yang dapat digunakan untuk memperkuat dan membandingkan hasil perhitungan manual yang telah dilakukan peneliti sebagai berikut:

Tabel 9. Analisis Regresi Berganda Pengaruh Inflasi $\left(X_{1}\right)$ dan Debt to Equity Ratio (DER) $\left(\mathrm{X}_{2}\right)$ terhadap Return Saham (Y) pada PT Unilever Indonesia, Tbk. Periode 2005 - 2016 
KHAZANAH MULTIDISIPLIN

VOL 2 NO 22021

https://journal.uinsgd.ac.id/index.php/kl

Coefficients $^{\mathrm{a}}$

\begin{tabular}{|c|c|c|c|c|c|}
\hline \multirow[b]{2}{*}{ Model } & \multicolumn{2}{|c|}{ Unstandardized Coefficients } & \multirow{2}{*}{\begin{tabular}{|l} 
Standardized \\
Coefficients
\end{tabular}} & \multirow[b]{2}{*}{$\mathrm{t}$} & \multirow[b]{2}{*}{ Sig. } \\
\hline & B & Std. Error & & & \\
\hline (Constant) & 50.675 & 19.929 & & 2.543 & .032 \\
\hline Inflasi & -.468 & 1.328 & -.113 & -.352 & .733 \\
\hline DER & -15.089 & 8.504 & -.572 & -1.774 & . 110 \\
\hline
\end{tabular}

a. Dependent Variable: Return

Sumber: SPSS For Windows 16.0

Dari hasil perhitungan di atas, maka didapatlah hasil yang menguji antara Inflasi $\left(\mathrm{X}_{1}\right)$ dan Debt to Equity Ratio (DER) $\left(\mathrm{X}_{2}\right)$ terhadap Return Saham (Y) sebagai berikut :

$\mathrm{Y}=\mathrm{a}+\mathrm{b}_{1} \mathrm{X}_{1}+\mathrm{b}_{2} \mathrm{X}_{2}$

$\mathrm{Y}=50,675-0,468 \mathrm{X}_{1}-15,089 \mathrm{X}_{2}$

Return Saham $=50,675-0,468$ Inflasi $-15,089$ Debtto Equity Ratio

$\mathrm{a}=50,675$

Konstanta sebesar 50,675 menunjukkan bahwa ketika Tidak Ada Inflasi $\left(\mathrm{X}_{1}\right)$ dan Debt to Equity Ratio (DER) $\left(\mathrm{X}_{2}\right)$, maka nilai untuk Return Saham (Y) sebesar 50,675\%.

$b_{1}=-0,468$

Koefisien sebesar - 0,468 menunjukkan jika Inflasi $\left(\mathrm{X}_{1}\right)$ naik sebesar 1\% (diasumsikan semua variabel konstan) maka Return Saham (Y) memiliki nilai sebesar - 0,468\%.

$\mathrm{b}_{2}=-15,089$

Koefisien sebesar -15,089 menunjukkan jika Debt to Equity Ratio (DER) $\left(\mathrm{X}_{2}\right)$ naik sebesar 1\% (diasumsikan semua variabel konstan) maka Return Saham (Y) memiliki nilai sebesar -15,089\%.

\section{Analisis Korelasi Ganda}

Analisis Korelasi Ganda berfungsi untuk mencari besarnya hubungan dan kontribusi dua variabel independent (X) atau secara simultan (bersama - sama) dengan variabel dependent (Y). Berikut hasil perhitungan analisis korelasi berganda adalah sebagai berikut : 
Tabel 10. Analisis Korelasi Berganda Pengaruh Inflasi $\left(X_{1}\right)$ dan Debt to Equity Ratio (DER) $\left(\mathrm{X}_{2}\right)$ terhadap Return Saham (Y) pada PT Unilever Indonesia,Tbk. Periode 2005 - 2016

Correlations

\begin{tabular}{|ll|l|l|l|}
\hline & & Return & Inflasi & DER \\
\hline Pearson & Return & 1.000 & .159 & -.518 \\
Correlation & Inflasi & .159 & 1.000 & -.476 \\
& DER & -.518 & -.476 & 1.000 \\
\hline Sig. (1-tailed) & Return &. & .311 & .042 \\
& Inflasi & .311 &. & .059 \\
& DER & .042 & .059 & 12 \\
\hline R & Return & 12 & 12 & 12 \\
& Inflasi & 12 & 12 & 12 \\
\hline
\end{tabular}

Sumber: SPSS For Windows 16.o, data diolah: 2016

Dari Tabel diatas dapat diperoleh nilai korelasi atau hubungan Inflasi ( $\mathrm{X}_{1}$ ) terhadap Return Saham (Y) secara parsial sebesar 0,159 yaitu dikategorikan pada hubungan yang sangat lemah dan menunjukkan hubungan positif. Sedangkan nilai korelasi atau hubungan Debt to Equity Ratio (DER) ( $\mathrm{X}_{2}$ ) terhadap Return Saham (Y) secara parsial sebesar -0,518 yaitu dikategorikan pada hubungan yang cukup kuat dan menunjukan hubungan yang negatif. Sedangkan untuk korelasi atau hubungan Inflasi $\left(\mathrm{X}_{1}\right)$ dan Debt to Equity Ratio (DER) $\left(\mathrm{X}_{2}\right)$ terhadap Return Saham $(\mathrm{Y})$ secara simultan berdasarkan hasil perhitungan SPSS for Windows Versi 16.0 adalah sebagai berikut: 
KHAZANAH MULTIDISIPLIN

VOL 2 NO 22021

https://journal.uinsgd.ac.id/index.php/kl

Tabel 11. Analisis Korelasi Berganda Pengaruh Inflasi $\left(X_{1}\right)$ dan Debt to Equity Ratio (DER) $\left(\mathrm{X}_{2}\right)$ terhadap Return Saham (Y) pada PT Unilever Indonesia,Tbk. Periode 2005 - 2016

Model Summary

\begin{tabular}{|l|l|c|l|l|}
\hline Model & $\mathrm{R}$ & R Square & Adjusted R Square & $\begin{array}{l}\text { Std. Error of the } \\
\text { Estimate }\end{array}$ \\
\hline 1 & $.527^{\mathrm{a}}$ & .278 & .117 & 15.97351 \\
\hline
\end{tabular}

a. Predictors: (Constant), DER, Inflasi

b. Dependent Variable: Return

Dari tabel diatas dapat diperoleh nilai korelasi atau hubungan Inflasi $\left(\mathrm{X}_{1}\right)$ dan Debt to Equity Ratio (DER) $\left(\mathrm{X}_{2}\right)$ terhadap Return Saham (Y) secara simultan sebesar 0,527. Artinya hubungan antara Inflasi $\left(\mathrm{X}_{1}\right)$ dan Debt to Equity Ratio (DER) ( $\mathrm{X}_{2}$ ) terhadap Return Saham (Y) apabila mengacu pada tabel Interpretasi Korelasi dapat dikategorikan "Sedang” dan menunjukan hubungan positif.

Dari hasil uji korelasi, untuk mengetahui bagaimana hubungan Inflasi $\left(\mathrm{X}_{1}\right)$ dan Debt to Equity Ratio (DER) $\left(\mathrm{X}_{2}\right)$ terhadap Return Saham (Y) baik secara parsial maupun simultan, berikut merupakan tabel yang menjelaskan mengenai hasil pengujian baik secara parsial maupun secara simultan.

Tabel 12. Hasil Analisis Korelasi Hubungan Inflasi $\left(X_{1}\right)$ dan Debt to Equity Ratio (DER) $\left(\mathrm{X}_{2}\right)$ terhadap Return Saham (Y) pada PT Unilever Indonesia, Tbk. periode 2005-2016

\begin{tabular}{|c|c|c|}
\hline Variabel & Signifikansi & Keterangan \\
\hline $\begin{array}{l}\text { Inflasi }\left(\mathrm{X}_{1}\right) \text { terhadap Return Saham } \\
\text { (Y) }\end{array}$ & 0,159 & $\begin{array}{l}\text { Berdasarkan hasil Uji } \text { Korelasi } \\
\text { diperoleh nilai o,519, dimana bila dilihat } \\
\text { dari tabel Interpretasi Koefisien } \\
\text { Korelasi menunjukkan hubungan yang } \\
\text { "Sangat Lemah" antara Inflasi (X1) } \\
\text { Return Saham (Y) PT Unilever } \\
\text { Indonesia, Tbk. }\end{array}$ \\
\hline $\begin{array}{l}\text { Debt to Equity Ratio (DER) }\left(\mathrm{X}_{2}\right) \\
\text { terhadap Return Saham (Y) }\end{array}$ & $-0,518$ & $\begin{array}{l}\text { Berdasarkan hasil Uji Korelasi } \\
\text { diperoleh nilai -0,518, dimana } \\
\text { bila dilihat dari tabel Interpretasi } \\
\text { Koefisien Korelasi menunjukkan } \\
\text { hubungan yang "Sedang" antara Debt to } \\
\text { Equity Ratio (DER) }\left(\mathrm{X}_{2}\right) \text { terhadap }\end{array}$ \\
\hline
\end{tabular}




\begin{tabular}{|c|c|c|}
\hline & & $\begin{array}{l}\text { Return Saham } \\
\text { Indonesia, Tbk. }\end{array}$ \\
\hline $\begin{array}{l}\text { Inflasi }\left(\mathrm{X}_{1}\right) \text { dan Debt to Equity Ratio } \\
\text { (DER) }\left(\mathrm{X}_{2}\right) \text { terhadap Return Saham } \\
\text { (Y) }\end{array}$ & 0,527 & $\begin{array}{l}\text { Berdasarkan hasil Uji } \text { Korelasi } \\
\text { diperoleh nilai } 0,527 \text {, dimana bila } \\
\text { dilihat dari tabel Interpretasi Koefisien } \\
\text { Korelasi menunjukkan hubungan yang } \\
\text { "Sedang" antara Inflasi }\left(\mathrm{X}_{2}\right) \text { dan Debt to } \\
\begin{array}{lllll}\text { Equity ratio } & \text { (DER) } & \left(\mathrm{X}_{2}\right) & \text { terhadap } \\
\text { Return Saham } & (\mathrm{Y}) & \text { PT } & \text { Unilever } \\
\text { Indonesia, Tbk. } & & \end{array}\end{array}$ \\
\hline
\end{tabular}

\section{Koefisien Determinasi}

Besarnya pengaruh Inflasi $\left(\mathrm{X}_{1}\right)$ dan Debt to Equity Ratio (DER) $\left(\mathrm{X}_{2}\right)$ terhadap Return Saham (Y) dapat diketahui dari perhitungan koefisiensi determinasi sebagai berikut.

Tabel 13. Analisis Koefisien Determinasi Pengaruh Inflasi (X1) dan Debt to Equity Ratio (DER) $\left(X_{2}\right)$ terhadap Return Saham (Y) pada PT Unilever Indonesia, Tbk Periode 2005 - 2016

Model Summaryb

\begin{tabular}{|l|l|l|l|l|}
\hline Model & R & R Square & $\begin{array}{l}\text { Adjusted } \\
\text { Square }\end{array}$ & $\begin{array}{l}\text { Std. Error of the } \\
\text { Estimate }\end{array}$ \\
\hline 1 & $.527^{\mathrm{a}}$ & .278 & .117 & 15.97351 \\
\hline
\end{tabular}

a. Predictors: (Constant), DER, Inflasi

b. Dependent Variable: Return

Sumber: SPSS For Windows 16.o, data diolah: 2016

Berdasarkan perhitungan manual menunjukkan $\mathrm{R}^{2}$ menerangkan tingkat hubungan antar variabel independent (X). Dari tabel $\mathrm{R}$ menunjukkan bahwa R square atau Koefisien Determinasi memiliki nilai 0,278 yang artinya terdapat hubungan antara Inflasi $\left(\mathrm{X}_{2}\right)$ dan Debt to Equity Ratio (DER) ( $\mathrm{X}_{2}$ ) terhadap Return Saham (Y) sebesar 27,8\%, sedangkan $72,2 \%$ dipengaruhi oleh variabel lain yang tidak penulis teliti. 


\section{Uji Statistik F}

Uji F digunakan untuk menguji signifikansi pengaruh Inflasi $\left(\mathrm{X}_{1}\right)$ dan Debt to Equity Ratio (DER) ( $\mathrm{X}_{2}$ ) terhadap Return Saham (Y) secara simultan. Perhitungan Uji F dengan taraf signifikansi $\alpha=0,05(5 \%)$. Berikut adalah perhitungannya:

Tabel 14. Uji F Pengaruh Inflasi $\left(X_{1}\right)$ dan Debt to Equity Ratio (DER) $\left(X_{2}\right)$ terhadap Return Saham (Y) pada PT Unilever Indonesia, Tbk. Periode 2005 $-2016$

\section{ANOVA $^{\mathrm{b}}$}

\begin{tabular}{|ll|l|l|l|l|l|}
\hline Model & Sum of Squares & Df & Mean Square & F & Sig. \\
\hline 1 & Regression & 883.381 & 2 & 441.691 & 1.731 & $.231^{\mathrm{a}}$ \\
& Residual & 2296.376 & 9 & 255.153 & & \\
Total & 3179.757 & 11 & & & \\
\hline
\end{tabular}

a. Predictors: (Constant), DER, Inflasi

b. Dependent Variable: Return

Sumber: SPSS For Windows 16.0

Berdasarkan perhitungan di atas diperoleh $\mathrm{F}$ hitung sebesar 1,731. Sedangkan hasil dari $\mathrm{F}_{\text {tabel dengan }(k-1)}(n-k)$, dimana $k$ adalah jumlah variabel bebas dan terikat dan $\mathrm{N}$ adalah banyak data, maka (3-1) (12-3) diperoleh $\mathrm{F}$ tabel 4,26 dan taraf signifikansinya 5\%. Karena hasil dalam data

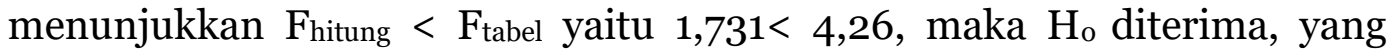
artinya terdapat pengaruh yang tidak signifikan secara bersama-sama

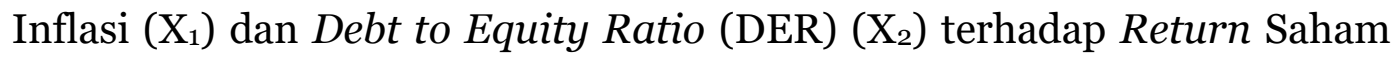
(Y) PT Unilever indonesia, Tbk. Sehingga hasil penelitian ini tidak berlaku secara umum, hanya pada ojek penelitian yang saat ini diteliti saja.

Apabila divisualisasikan, maka Pengaruh Inflasi $\left(\mathrm{X}_{1}\right)$ dan Debt to Equity Ratio (DER) ( $\mathrm{X}_{2}$ ) terhadap Return Saham (Y) PT Unilever indonesia, Tbk. dapat di lihat pada gambar 1 di bawah ini: 
KHAZANAH MULTIDISIPLIN

VOL 2 NO 22021

https://journal.uinsgd.ac.id/index.php/kl

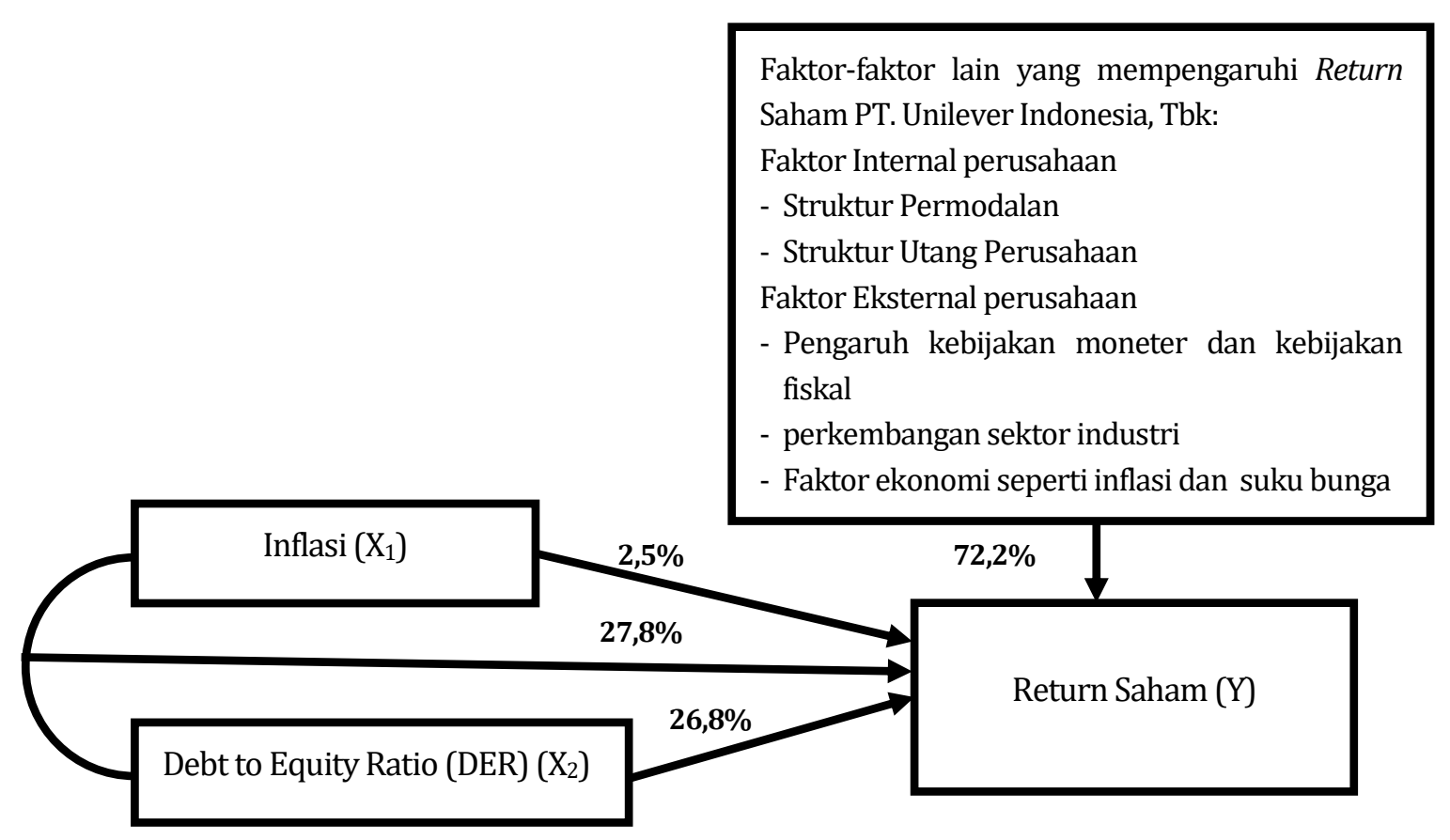

Gambar 1. Pengaruh Inflasi $\left(X_{1}\right)$ dan Debt to Equity Ratio (DER) $\left(\mathrm{X}_{2}\right)$ terhadap Return Saham (Y) PT. Unilever Indonesia, Tbk. Periode 2005-2016

\section{SIMPULAN}

Penelitian ini menunjukkan hasil uji signifikansi yang cukup kuat antara Debt to Equity Ratio (DER) terhadap Return Saham (Y) yang berarti bahwa Rasio Solvabilitas yaitu Debt to Equity Ratio (DER) terkhusus dalam penelitian ini memiliki hubungan yang cukup erat terhadap pembagian 
KHAZANAH MULTIDISIPLIN

VOL 2 NO 22021

https://journal.uinsgd.ac.id/index.php/kl

Return Saham pada perusahaan yang listing di Jakarta Islamic index (JII) terutama di PT Unilever indonesia, Tbk. Penelitian ini pun memberikan informasi bahwa secara bersama-sama Inflasi $\left(\mathrm{X}_{1}\right)$ dan Debt to Equity Ratio (DER) $\left(\mathrm{X}_{2}\right)$ berpengaruh negatif dan cukup kuat terhadap Return Saham (Y). Secara simultan hasil penelitian ini memperkuat penelitian sebelumnya. Hasil penelitian ini menunjukan bahwa faktor internal perusahaan lebih berpengaruh besar terhadap pembagian return saham perusahaan, dibandingkan dengan faktor eksternal perusahaan yang mana dalam penelitian ini tidak memberikan pengaruh yang begitu signifikan.

\section{DAFTAR PUSTAKA}

Afrilia, A. (2020) “Aplikasi Analisis Hirarki Proses pada Model Internal Rating Credit Line Bagi Bank Syariah,” Khazanah Sosial, 2(2), pp. 4956.

Arisa, A. (2017) “Analisis Perbandingan Pendekatan Anuitas dan Flat dalam Murabahah," in Prosiding Seminar Nasional Ekonomi dan Keuangan Syariah di Indonesia: Antara Cita-Cita dan Realita. Jakarta: Sps UIN Jakarta Press.

Fadilah Haidar (2015) "Perlindungan Hukum Bagi Investor Terhadap Praktik Kejahatan Insider Trading Pada Pasar Modal Di Indonesia," Jurnal Cita Hukum, FSH UIN Syarif Hidayatullah Jakarta, 3(1), pp. $133-152$.

Fathoni, H. (2021) "PERAN PASAR MODAL SYARIAH DALAM LAJU PERTUMBUHAN EKONOMI DI INDONESIA," Khazanah Multidisiplin, 2(1), pp. 33-44.

Karim, A. A. (2012) Ekonomi Makro Islam. Jakarta: PT RajaGrafindo Persada.

Khairunnisa, N. A. (2020) "PENGARUH JUMLAH PENGHASILAN MARGIN PEMBIAYAAN MURABAHAH DAN ISTISHNA TERHADAP LABA PERUSAHAAN PERBANKAN DI INDONESIA," Khazanah Multidisiplin, 1(1), pp. 61-71.

Laely Purnamasari (2017) "Pengaruh Inflasi, Nilai Tukar Dolar, Return On Asset (ROA), Debt to Equity Ratio (DER) dan Current Ratio (CR) Terhadap Return Saham," Jurnal AKP, 7(2).

Martono, N. (2019) “Metode penelitian kuantitatif.” Rajawali Pers.

Noorchasanah, N. (2020) "Hak Pendapatan Pekerja Perempuan dalam AlQur'an," Khazanah Theologia, 2(2), pp. 111-118. 
KHAZANAH MULTIDISIPLIN

VOL 2 NO 22021

https://journal.uinsgd.ac.id/index.php/kl

Prasetyo, Y. (2018) "Perbandingan Risiko Dan Return Investasi Pada Indeks Lq 45 Dengan Indeks Jakarta Islamic Index (JII)," El-Jizya : Jurnal Ekonomi Islam, 6(2), pp. 287-310. doi: 10.24090/ej.v6i2.2043.

Prihantini, R. (2009) Analisis Pengaruh Inflasi, Nilai Tukar, ROA, DER dan CR terhadap Return Saham. Universitas Diponegoro Semarang.

Senjani, Y. P. and Wibantoro, R. I. (2018) "Information Content Hypotesis Pada Saham Terindeks JII," Akuntabilitas, 11(2), pp. 281-292. doi: 10.15408/akt.v11i2.8790.

Sugiono (2013) Statistika untuk Penelitian. Bandung: Alfabeta.

Sulaeman, M. et al. (2018) "Pengaruh Debt To Equity Ratio Dan Non Performing Loan Terhadap Return Saham Emiten Bursa Efek Indonesia Subsektor Perbankan," Jurnal Ilmiah Manajemen dan Bisnis, 19(1), pp. 21-31.

Suyati, S. (2015) "Pengaruh Inflasi,Tingkat Suku Bunga Dan Nilai Tukar Rupiah/Us Dollar Terhadap Return Saham Properti Yang Terdaftar Di Bursa Efek Indonesia," Serat Acitya-Jurnal Ilmiah UNTAG Semarang, 4(3).

Syahbudi, M. and Barus, E. E. (2019) "Mewujudkan Masyarakat Yang Sadar Investasi Syariah (Studi Persepsi Masyarakat Kota Medan),” Jurnal Ilmu Ekonomi dan Keislaman, 7(2), pp. 208-223.

Tandelilin (2001) Analisis Investasi dan Manajemen Portofolio. Pertama. Yogyakarta: BPFE Yogyakarta.

Wiryadinata, H. (2020) "Religious Human Resources Management: Perichoresis to manage or to be managed?," Khazanah Theologia, 2(2), pp. 103-110. 